\title{
Early Marriage Consequences in the Most Deprived Areas in Menoufia Governorate-Egypt: A Community-Based Survey
}

Taghreed M Farahat ${ }^{1}$, Hala M Shaheen ${ }^{1}$, Nora A Khalil ${ }^{1}$, Nagwa N Hegazy ${ }^{1}$, Rofida M Alsaqa ${ }^{1}$

${ }^{1}$ Family Medicine Department, Faculty of Medicine, Menoufia University

\begin{abstract}
:
Background: Early marriage is a violation of the basic human rights and is considered a public health problem. It has a profound range of physical, intellectual, psychological and social consequences on the teenager girls and their future children. Objectives: The current study aimed to assess the prevalence of early marriage and the associated social and health hazard.

Methods: A cross-sectional study was conducted among 1080 married women in the most deprived areas in Menoufia Governorate. All women were interviewed personally using a structured valid reliable Arabic questionnaire. It assessed the socio-demographic characteristics of the participants and their husbands, the socioeconomic state, social and health hazards of early marriage.

Results: About $48 \%$ of women were married before the age of 18 years. The early marriage was significantly higher among illiterate women (59.9\%), those who were housewives (99.1\%), and married to illiterate husbands (48\%). The main social hazards among the early married group were the conflicts with the husband's family and isolation of women from her family. While anemia and recurrent chest problems were the main health hazards among their first child.

Conclusion: Early marriage has a wide prevalence in the selected areas. It was more prevalent among low-educated women, housewives, and married to low-educated husbands. It is continued to cause different social and health consequences for women and their children. Early marriage is a prevailing problem that needs a plan of action to be implemented with the support of the policymakers.
\end{abstract}

Key Words: Education, Prevalence, Social, Women.

\section{Introduction:}

Early marriage is defined by the United Nations Children Fund (UNICEF) as any marriage carried out below the age of 18 years. Before this age the girl is physically mature and psychologically developed, and become ready to carry the responsibilities of the marriage and childbearing. ${ }^{1}$ Marriage before 18 years is widely acknowledged to be a harmful sociocultural practice and a widespread violation of human rights. It is an impediment to social and economic development. ${ }^{2}$ The UNICEF had reported in 2014 that one in four girls globally is married before the age of 18 years. In low and middle-income countries, early marriage is widely spread; with one in three girls is married before the age of 18 years, and one in nine is married before their fifteenth birthday. At the leastdeveloped countries, it's even higher, about nearly one in two. The report also warned that, if there is no reduction in early marriage, 1.2 billion girls will marry as children by $2050 .^{3}$ In the Arab region, one in seven girls is married before their $18^{\text {th }}$

*Corresponding author: E-mail: rofidaalsaqa90@ gmail.com 
birthday such as; South Sudan, Sudan, Yemen, and Somalia. ${ }^{4}$

The early marriage had health, social, economic, and political implications for the girls and the community. It makes the girl's legally under the custody of their husbands and great limitation to their freedom and independence. ${ }^{5}$ It limited the young women's lives, compromise their reproductive health and choices, specifically marriage practices such as the involvement of women in spouse choice, power in marital relationships, spousal communication and interaction, selfefficacy and gender-role attitudes. Also, differences in the age between women and men at marriage make more problems. ${ }^{6}$

It typically coincides with early childbearing. Young first-time mothers face increased risk of women's health, as maternal disorders, including complications during pregnancy and childbirth. Also, it is considered a leading cause of death among women aged 20-24 years globally, and the second leading cause of death among adolescent girls aged 15 - 19 years. ${ }^{7}$ Despite the law amendments, in Egypt, about 23\% of girls were married before the age of 18 , and the early marriage was an age-old tradition entrenched in the culture. ${ }^{8}$ Based on data from the Demographic and Health Survey for Egypt, the incidence of early marriage considered high as one in six women ages 18-22 years marry under the age of 18 years, and a smaller proportion before the age of 15 years. ${ }^{9}$

The present study was conducted to assess the prevalence of early marriage among married women in the most deprived areas in Menoufia Governorate through household surveys. Also, the study aimed to assess the associated social and health hazards of early marriage among women and their children.

\section{Methods:}

The study was a cross-sectional study carried out in the most deprived areas (Ezba) in Menoufia Governorate near our workplace. ${ }^{10}$ Two deprived areas were selected; Ezbat El-Maadawy, in Menouf districts, and Ezbat El-Anania in El-Shohadaa districts ${ }^{(11)}$ during the period from the $1^{\text {st }}$ of April 2017 to the end of August 2018. All married women aged from 15 to 49 years living in the two deprived areas were included in the study.

A workshop was held over two days for training of data collectors; explaining to them the different parts of the questionnaire and the proper way to ask the questions. The 
role-play technique was used to ensure their competence. Twenty persons were eligible for data collection and they conducted several visits to the two selected deprived areas (ten interviewers for each village and four coordinators for supervision).

Before the beginning of the field work, a pilot study was done. It aimed to test the adequacy of the questionnaire sheets (contents, language, time-consuming) and to explore the potential obstacles and difficulties that may be faced in the study. It was done through a visit to each deprived area, and a convenience sample of twenty accepted subjects. They were excluded from the study later.

All married women were subjected to an interview using a designed Arabic structured questionnaire consists of three sections.

The first section: It included the sociodemographic data of the woman and her husband, such as the name of the women, her age....etc. Also, questions about socioeconomic data such as education, occupation ... etc. Evaluation of the socioeconomic status based on Fahmy et al socioeconomic scoring system. ${ }^{12}$

The second section: It included questions to explore the possible social hazards related to early marriage such as conflicts with the husband's family, husband needs, domestic violence, sexual problems, isolation of women from her own family, divorce and second marriage of the husband. The third section: included two parts, the first part about health problems among the women such as the number of abortion, pregnancyrelated problems, and inter-pregnancy space duration.

The second part noted the most common health problem of their first child such as anemia, rickets, and recurrent chest infections and gastrointestinal tract infections. A cross-sectional household survey was carried out in each deprived area, and a purposive sample of 1080 married women in reproductive age (15-49 years) from all the population was taken.

Ethical Consideration: The study was approved by the Research Ethics Committee of the Faculty of Medicine, Menoufia University. An informed written consent was taken from each participant after a simple and clear explanation about the research goals and potential benefit.

Statistical analysis: Data were collected, tabulated, statistically analyzed using an IBM personal computer with Statistical 
Package for Social Science (SPSS) version 23. Qualitative data were expressed in the form numbers and percentage and analyzed by using a Chi-squared test $\left(\mathrm{X}^{2}\right)$ to detect the relation between different qualitative variable. Quantitative data were expressed in the form of a mean, standard deviation (SD) and analyzed by using Student $\mathrm{t}$ - test for comparison between two groups having qualitative variables. A probability value (Pvalue) less than 0.05 was considered statistically significant and was high statistically signification if $(\mathrm{P}<0.01)$.

\section{Results:}

Nearly half of the participants $(48 \%)$ were married before the age of 18 years. (Figure1).The study found that early marriage was significantly higher among illiterate women $(59.9 \%)$, those who were housewives (99.1\%). About (48\%) of husbands of studied women were illiterate and (52\%) of them were unskilled worker (a worker who does not use intellectual abilities in their line of work and typically found in positions that involve manual labor such as baker, porter, driver, assembler, or apprentice) (Table-1).

About $(92.9 \%)$ of the early married women had a low socioeconomic status. Also, consanguinity was significantly among (36.4\%) of them (Table-1). Regarding the social hazards related to marriage; the study found that conflicts with the husband's family $(48.9 \%)$, social isolation of the women from their family (18.1\%), domestic violence (11.7\%) and divorce (1.8), were significantly higher among early married women (Table-2)..

The percentage of the number of abortions, preterm delivery and bleeding during pregnancy was significantly higher among the early married group (41.3\%, $9.8 \% \& 15.8 \%$ respectively). More than two years of inter-pregnancy space duration was significantly higher among women who married after the age of 18 years $(\mathrm{P}<0.001)$ (40.8\%) (Table-3).Regarding the health hazards related to their first child, the frequency of anemia and recurrent chest infections was significantly more among the first child of early married women $(7.8 \%$ and $11.4 \%$ respectively) than others. While the frequency of gastrointestinal tract infections and rickets showed no significant difference between both groups (Table 3).

\section{Discussion:}

In the current study, nearly half of the participants (48\%) were married before their eighteenth birthday. The study results were 
consistent with research in South Asia; where about (44\%) of women married before the age of 18 years. ${ }^{13}$ And it's in agreement with results of Hotchkiss et $\mathrm{al}^{14}$ study among Roma girls in Serbia, which found about $50 \%$ of the women married before the age of 18 years, especially women from poor families. A low level of education was significantly higher among the early married women, and the overwhelming majority of them were housewives. This is similar to the finding of Walker $^{15}$ study in Niger, Chad, and Mali, which reported that more than half of early married women with no formal education.

It was predicted by Wodon et al ${ }^{16}$ who suggest that each year of early marriage under 18 years can lead to a decrease of 4-6 percentage points in the chance of secondary school completion for girls. The study recorded that only six women of the early married group completed their education until the university after the marriage, as their husbands well-educated and haven't any problem with them to continue their education after marriage.

The husbands of the early married women also had a low level of education, and most of them were unskilled workers such as baker, porter, driver, assembler, or apprentice. This result is nearly in agreement with the findings of Ghrayeb et al. ${ }^{17}$ study that conducted in a rural area, Palestine, which recorded that prevalence of early marriage was wide among illiterate husbands, but there no statistical differences between the husband's occupation and early marriage. In the current study, most of the women who were married early have a lower socioeconomic status. This is in concordance with De Groot et al. ${ }^{18}$ and Le Strat et al. ${ }^{19}$ studies (in northern Ghana and the United States respectively). These studies found that early marriage was recorded among poor and low educated women, those living in rural areas.

The consanguineous marriage was significant among the women who were married early, which is similar to the results of Ghrayeb et al. ${ }^{17}$ study. The study illustrates the different social hazards related to early marriage such as the conflicts with the husband's family, isolation of women from her family, domestic violence, and divorce. This is consistent with Parsons et al. $^{20}$ given evidence that early married women have typically little bargaining power within the household. While Le Strat et al. ${ }^{19}$ study reported that early marriage associated with 
higher rates of divorce $(48.41 \%)$ and the widowing $(14.83 \%)$, relative to adult marriage $\quad(27.82 \% \quad$ and $\quad 11.93 \%$ respectively).

The percentage of the abortion number, preterm delivery, and bleeding during pregnancy was significantly higher among the women who married earlier than others. Also, the inter-pregnancy space duration was being significantly short among them. This comes in parallel to results of Raj et al. $^{21}$ study in India, which revealed that about $(23.0 \%)$ of early married women reported a history of rapid repeat childbirth with short inter-pregnancy space. Also, about $(15.3 \%)$ of them reported a history of pregnancy termination (i.e. miscarriage, abortion, or stillbirth).

In the current study, the frequency of anemia and recurrent chest infections was more prevalent among the first child of the early married women. While the frequency of gastroenteritis infections and rickets showed no significant difference between both groups. This nearly similar the result of Raj et al. ${ }^{21}$ study, which found that about (10.6\%) of children born to early married women had experienced acute respiratory infection, a similar proportion (10.3\%) experienced diarrhea. On the contrary, the study of De Groot et al. ${ }^{18}$ showed firstborn children of early married women had increased mortality rate compared to the first-born of married women after the age of 18 years.

\section{Study limitation:}

Difficulty in reaching out the deprived area (Ezba) was evident since it was isolated from surrounding cities and villages. Also, disclosing or talking about the personal issues for some participants was unavoidable difficulty. Trying to overcome such difficulties through:

- Explaining the purpose and benefit of the research to every participant and assuring that the data will be kept confidential.

- Comfortable place and good communication skills with the participants to allow them relive their fears and speak comfort that allow disclose all required information.

\section{Conclusion:}

Early marriage had a wide prevalence about $(48 \%)$ in two studied deprived areas in Menoufia Governorate. It was more prevalent among low-educated women, housewives, low-educated husbands, and among low-economic state families. It's continued to cause different social and 
health consequences for women and their children. Early marriage is a prevailing problem that needs a plan of action to be implemented with the support of the policymakers.

Conflict of interest: No conflict of interest to declare.

Acknowledgment: The authors of the paper would like to thank all participants of the study, the field workers, the Municipality of a deprived area, Menouf discrete, and the higher education ethical committee of Menoufia University.

\section{References:}

1. United Nations Children Fund (UNICEF). Working towards a common goal: ending child marriage. 2011. https://www.unicefusa.org/stories/worki ng-towards-common-goal-ending-childmarriage/7086. Accessed January 9, 2019

2. Parsons J, Edmeades J, Kes A, Petroni S et al. Economic impacts of child marriage: a review of the literature. The Review of Faith \& International Affairs. 2015; 13(3): 12-22.

3. United Nations Children Fund (UNICEF). Ending Child Marriage: Progress and Prospects. State of the World's Children: In Numbers: Every
Child Counts. 2014. https://data.unicef.org/resources/endingchild-marriage-progress-and-prospects/. Accessed January 9, 2019.

4. Roudi-Fahimi F, Ibrahim S. Ending child marriage in the Arab region. policy brief, Ford Foundation office in Cairo. Population Reference Bureau. 2013; 1(8). https://www.prb.org/childmarriage-mena/ Accessed 9 January, 2019.

5. Zahangir M. Early and Very Early Family Formation in Bangladesh. 2011.http://www.divaportal.org/smash/r ecord.jsf?pid=diva2\%3A432607\&dswid $=8173$. Accessed 9 January, 2019.

6. Santhya K, Ram U, Acharya R et al. Associations between early marriage and young women's marital and reproductive health outcomes: evidence from India. International Perspectives on Sexual and Reproductive Health. 2010;36(3):132-139.

7. Mokdad A, Forouzanfar M, Daoud F et al. Global burden of diseases, injuries, and risk factors for young people's health during 1990-2013: a systematic analysis for the Global Burden of Disease Study 2013. The Lancet. 2016; 387(10036): 2383-240. 
8. United Nations Human Rights Council. Panel discussion on preventing and eliminating child, early and forced marriage. 2014. Twenty-sixth session. https://nhri.ohchr.org/EN/IHRS/Human RightsCouncil/26/Update\%20by\%20the $\% 20$ High\%20Commissioner\%20followe d\%20by\%20Genera/Forms/Default\%20 View.aspx. Accessed 9 January, 2019.

9. The World Bank Statistics. http://enid.org.eg/uploads/Pdf/Pb15_pov ertyprofile_egypt.pdf

10. El-Zanaty, F. Egypt Demographic and Health Survey 2014, Ministry of Health and Population Cairo, Egypt, The DHS Program, ICF International Rockville, Maryland, USA. 2015.

11. El-Tawila S, Gadalla M, Ali E. Income Poverty and Inequality in Egypts Poorest Villages. In The World Bank and Social Contract Center, Experts' Group Meeting, May 27th, Cairo, Egypt. 2013.

12. Fahmy S, Nofal L, Shehata $\mathrm{S}$ et al. Updating indicators for scaling the socioeconomic level of families for health research. The Journal of the Egyptian Public Health Association. 2015; 90(1):1-7.

13. United Nations Children Fund (UNICEF). Child marriage: Latest trends and future prospects. 2018. https://data.unicef.org/resources/childmarriage-latest-trends-and-futureprospects/. Accessed 9 January 2019.

14. Hotchkiss D, Godha D, Gage A et al. Risk factors associated with the practice of child marriage among Roma girls in Serbia. BMC International Health and Human Rights. 2016; 16(1): 6-15.

15. Walker J. Early Marriage in Africa Trends, Harmful Effects and Interventions Zones of early marriages in Africa. African Journal of Reproductive Health. 2012; 16(2): 231240.

16. Wodon Q, Nguyen M, Tsimpo C. Child marriage, education, and agency in Uganda. Feminist Economics. 2016; 22(1): 54-79.

17. Ghrayeb F, Rusli A, Ismail I et al. Prevalence of early marriage among women in rural Palestinian community: A cross-sectional study. International Medical Journal. 2015; 22(4):291-294.

18. DeGroot R, Kuunyem M, Palermo T et al. Child marriage and associated outcomes in northern Ghana: A crosssectional study. BMC Public Health. 2018; 18(1), 285-297. 
19. Le-Strat, Y., Dubertret, C., Le-Foll, B. Child marriage in the United States and its association with mental health in women. Pediatrics. 2011; 128(3): 524530.

20. Parsons J, Edmeades J, Kes A et al. Economic impacts of child marriage: a review of the literature. The Review of Faith \& International Affairs. 2015; 13(3): 12-22.
21. Raj A, Saggurti N, Winter M et al. The effect of maternal child marriage on morbidity and mortality of children under 5 in India: cross sectional study of a nationally representative sample. BMJ. 2010; 340, b4258-b4267. 


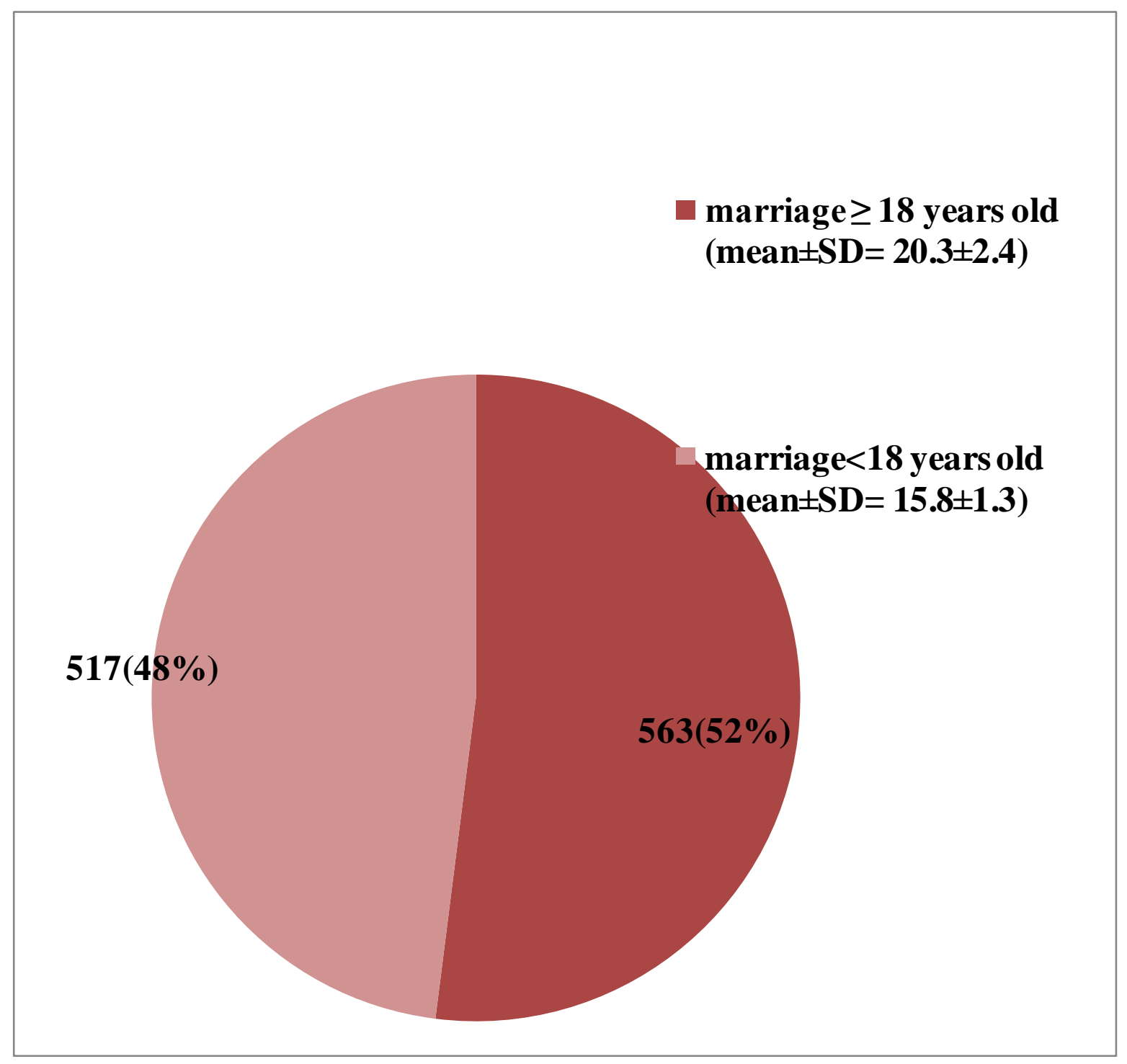

Figure (1): Prevalence of early marriage among the studied women 
Table (1): Comparison between the women married before and after the legal age of marriage regarding socio-demographic characteristics

\begin{tabular}{|c|c|c|c|c|c|c|c|c|}
\hline \multirow[t]{2}{*}{$\begin{array}{l}\text { Socio-demographic } \\
\text { characteristics }\end{array}$} & \multicolumn{2}{|c|}{$\begin{array}{c}\text { Group } 1 \\
<18 \text { years } \\
(563)\end{array}$} & \multicolumn{2}{|c|}{$\begin{array}{c}\text { Group } 2 \\
\geq 18 \text { years } \\
(517)\end{array}$} & \multicolumn{2}{|c|}{ Total $(1080)$} & \multirow[t]{2}{*}{$\mathrm{X} 2$} & \multirow[t]{2}{*}{$\begin{array}{c}\mathbf{P} \\
\text { value }\end{array}$} \\
\hline & No & $\%$ & No & $\%$ & No & $\%$ & & \\
\hline \multicolumn{9}{|c|}{ - Educational level of women } \\
\hline - Illiterate & 337 & 59.9 & 251 & 48.5 & 588 & 54.4 & \multirow{4}{*}{74.4} & \multirow{4}{*}{0.000} \\
\hline - Basic & 155 & 27.5 & 91 & 17.6 & 246 & 22.8 & & \\
\hline - Secondary & 65 & 11.5 & 143 & 27.7 & 208 & 19.3 & & \\
\hline - University & 6 & 1.1 & 32 & 6.2 & 38 & 3.5 & & \\
\hline \multicolumn{9}{|c|}{ - Occupation of women } \\
\hline - Housewife & 558 & 99.1 & 373 & 72.1 & 931 & 86.2 & \multirow[t]{2}{*}{164.7} & \multirow[t]{2}{*}{0.000} \\
\hline - Working & 5 & 0.9 & 144 & 27.9 & 149 & 13.8 & & \\
\hline \multicolumn{9}{|c|}{ - Husbands education } \\
\hline - Illiterate & 270 & 48.0 & 190 & 36.8 & 460 & 42.6 & \multirow{4}{*}{15.2} & \multirow{4}{*}{0.001} \\
\hline - Basic & 73 & 12.7 & 71 & 13.7 & 144 & 13.3 & & \\
\hline - Secondary & 179 & 31.8 & 202 & 39.1 & 381 & 35.3 & & \\
\hline - University & 41 & 7.3 & 54 & 10.4 & 95 & 8.8 & & \\
\hline \multicolumn{9}{|c|}{ Husbands occupation } \\
\hline - No work & 113 & 20.1 & 48 & 9.3 & 161 & 14.9 & \multirow{4}{*}{173.8} & \multirow{4}{*}{0.000} \\
\hline $\begin{array}{l}\text { Unskilled } \\
\text { worker }\end{array}$ & 293 & 52 & 298 & 57.6 & 591 & 54.7 & & \\
\hline - Employee & 12 & 2.1 & 127 & 24.6 & 139 & 12.9 & & \\
\hline - $\quad$ Farmer & 145 & 25.8 & 44 & 8.5 & 189 & 17.5 & & \\
\hline \multicolumn{9}{|c|}{ - Socioeconomic level } \\
\hline - Low & 523 & 92.9 & 387 & 74.9 & 910 & 84.3 & \multirow{3}{*}{66.1} & \multirow{3}{*}{0.000} \\
\hline - Medium & 40 & 7.1 & 130 & 25.1 & 170 & 15.7 & & \\
\hline - High & 0 & 0.0 & 0 & 0.0 & 0 & 0.0 & & \\
\hline \multicolumn{9}{|c|}{ - Consanguinity } \\
\hline - Yes & 205 & 36.4 & 120 & 23.2 & 325 & 30.1 & \multirow[t]{2}{*}{22.33} & \multirow[t]{2}{*}{0.000} \\
\hline - No & 358 & 63.6 & 397 & 76.8 & 755 & 69.9 & & \\
\hline
\end{tabular}


Table (2): Social hazards among the studied groups

\begin{tabular}{|c|c|c|c|c|c|c|c|c|}
\hline \multirow[t]{2}{*}{ Social hazards } & \multicolumn{2}{|c|}{$\begin{array}{l}\text { Group } 1 \\
<18 \text { years } \\
(563)\end{array}$} & \multicolumn{2}{|c|}{$\begin{array}{l}\text { Group } 2 \\
\geq \begin{array}{l}18 \text { years } \\
(517)\end{array}\end{array}$} & \multicolumn{2}{|c|}{$\begin{array}{l}\text { Total } \\
(\mathbf{1 0 8 0})\end{array}$} & \multirow[t]{2}{*}{$\mathbf{X} 2$} & \multirow[t]{2}{*}{$\begin{array}{c}\mathbf{P} \\
\text { value }\end{array}$} \\
\hline & No & $\%$ & No & $\%$ & No & $\%$ & & \\
\hline $\begin{array}{l}\text { Conflicts with the } \\
\text { husbands family }\end{array}$ & 273 & 48.9 & 189 & 36.6 & 462 & 42.7 & 15.6 & 0.000 \\
\hline - Husband needs & 40 & 7.1 & 24 & 4.6 & 64 & 5.9 & 2.9 & 0.06 \\
\hline - Domestic violence & 66 & 11.7 & 40 & 7.7 & 106 & 9.8 & 4.13 & 0.04 \\
\hline - Sexual problems & 37 & 6.6 & 37 & 7.2 & 74 & 6.9 & 0.14 & 0.70 \\
\hline $\begin{array}{l}\text { Isolation of women } \\
\text { from her own } \\
\text { family }\end{array}$ & 102 & 18.1 & 59 & 11.4 & 161 & 14.9 & 9.55 & 0.001 \\
\hline - Divorce & 10 & 1.8 & 2 & 0.4 & 12 & 1.1 & 4.7 & 0.03 \\
\hline $\begin{array}{l}\text { - Second marriage of } \\
\text { her husband }\end{array}$ & 9 & 1.6 & 3 & 0.6 & 12 & 1.1 & 2.5 & 0.11 \\
\hline
\end{tabular}


Table (3): Medical hazards among women and their first child of the studied group

\begin{tabular}{|c|c|c|c|c|c|c|c|c|}
\hline & \multicolumn{2}{|c|}{$\begin{array}{c}\text { Group } 1 \\
<\text { 18 years } \\
(563)\end{array}$} & \multicolumn{2}{|c|}{$\begin{array}{c}\text { Group } 2 \\
\geq 18 \text { years } \\
\quad(517)\end{array}$} & \multicolumn{2}{|c|}{ Total $(\mathbf{1 0 8 0})$} & \multirow[t]{2}{*}{$\mathbf{X} 2$} & \multirow[t]{2}{*}{$\begin{array}{c}\mathbf{P} \\
\text { Value }\end{array}$} \\
\hline & No & $\%$ & No & $\%$ & $\mathbf{N}$ & $\%$ & & \\
\hline \multicolumn{9}{|c|}{ - Medical hazards for women } \\
\hline $\begin{array}{l}\text { History of abortion: } \\
\text { - Yes } \\
\text { - No }\end{array}$ & $\begin{array}{l}233 \\
330\end{array}$ & $\begin{array}{l}41.3 \\
58.6\end{array}$ & $\begin{array}{l}135 \\
382\end{array}$ & $\begin{array}{l}26.2 \\
73.9\end{array}$ & $\begin{array}{l}368 \\
712\end{array}$ & $\begin{array}{l}34.1 \\
65.9\end{array}$ & 27.9 & 0.000 \\
\hline $\begin{array}{l}\text { Pregnancy related } \\
\text { problems: } \\
\text { - } \\
\text { - } \text { Preterm labor } \\
\text { - } \text { Gestational DM } \\
\text { - } \text { Gestational HTN }\end{array}$ & $\begin{array}{c}55 \\
89 \\
8 \\
1\end{array}$ & $\begin{array}{c}9.8 \\
15.8 \\
1.4 \\
0.17\end{array}$ & $\begin{array}{c}22 \\
50 \\
4 \\
3\end{array}$ & $\begin{array}{l}4.3 \\
9.7 \\
0.8 \\
0.6\end{array}$ & $\begin{array}{c}77 \\
139 \\
12 \\
4\end{array}$ & $\begin{array}{c}7.1 \\
12.9 \\
1.1 \\
0.4\end{array}$ & $\begin{array}{l}12.4 \\
9.05 \\
1.03 \\
1.18\end{array}$ & $\begin{array}{l}0.000 \\
0.003 \\
0.311 \\
0.277\end{array}$ \\
\hline $\begin{array}{c}\text { Inter-pregnancy spacing: } \\
\text { - } \quad<2 \text { years } \\
\text { - } \geq 2 \text { years }\end{array}$ & $\begin{array}{l}210 \\
177\end{array}$ & $\begin{array}{l}37.3 \\
20.8\end{array}$ & $\begin{array}{l}154 \\
211\end{array}$ & $\begin{array}{l}29.8 \\
40.8\end{array}$ & $\begin{array}{l}364 \\
388\end{array}$ & $\begin{array}{l}33.7 \\
35.9\end{array}$ & 10.9 & 0.000 \\
\hline \multicolumn{9}{|c|}{ - Medical hazards of their first child } \\
\hline - Anemia & 44 & 7.8 & 19 & 3.7 & 63 & 5.8 & 8.41 & 0.003 \\
\hline $\begin{array}{l}\text { Recurrent GIT } \\
\text { infections }\end{array}$ & 56 & 9.9 & 43 & 8.3 & 99 & 9.2 & 0.85 & 0.353 \\
\hline $\begin{array}{l}\text { - Recurrent chest } \\
\text { infections }\end{array}$ & 64 & 11.4 & 39 & 7.5 & 103 & 9.5 & 4.56 & 0.032 \\
\hline - $\quad$ Rickets & 6 & 1.1 & 5 & 1.0 & 11 & 1.0 & 0.02 & 0.871 \\
\hline
\end{tabular}


الملخص العربى

الزواج المبكر وعواقبه في أكثر المناطق حرمانا في محافظة المنوفية ـ مصر: مسح مجتمعي

تغريد حمح فرحات - هالة محم شاهين - نور ا عبدالهادي خليل ـ نجوى نشأت حجازي- رفيدة ححم السقا قسم طب الأسرة - كلية الطب - جامعة المنوفية

الظلفية: يعتبر الزواج المبكر انتهاكًا لحقوق الإنسان الأساسية ويعتبر مشكلة صحية عامة. وله مجمو عة عميقة من العو اقب الجسدية و الفكرية و النفسية و الاجتماعية على الفتيات المر اهقات و أطفالهن في المستقبل. الأهداف: تقييم مدى انتشار الزواج المبكر وما يرتبط به من مخاطر إجتماعية وصحية. المنهجية و طرق البحث: أجريت در اسة مستعرضة بين 1080 امر أة متزوجة في أكثر المناطق حرمانا في محافظة المنوفيـة. تمت مقابلة جميع النساء شخصيًا باستخدام استبيان عربي منظم و موثوق به ـ قيم الاستبيان الخصائص الثخصية للمشاركات وأزواجهن ، و الحالة الاجتماعية والاقتصادية لهن ، و المخاطر الاجتماعية و الصحية للزواج المبكر. النتائج: أظهرت النتائج أن حو الي 48٪ من النساء قد تزوجن قبل سن 18 عام. كان الزواج المبكر أعلى بشكل ملحوظ بين النسـاء الأميات (59.9 ٪) ، وبين ربات البيوت (99.1 ٪) ، أيضا كان أزو اجهم أميين (48 ٪). كانت المخـاطر الاجتماعية الرئيسية بين مجمو عة النساء اللاتي تزوجن باكر ا هي الصر اعات مع أسرة الزوج و انعز ال المر أة عن عائلتها. في حين كان فقر الدم و التهابـات الصدر المتكررة هي المخاطر الصحية الرئيسية لأول أطفالهن. الإستنتاج: الزواج المبكر له انتشار و اسع في المناطق المختارة. وقد وجد بين النساء ذوات التعليم المتدني ، وربـات البيوت ، أيضـا أزواجهم ذو تعليم متدني. استمر الزواج المبكرفي تسبب عو اقب اجتماعية وصحية مختلفة للفتيات وأطفالهن.إن الزواج المبكر مشكلة سائدة تحتاج إلى تنفيذ خطة عمل بدعم من صانعي السياسات. الكلمات المفتاحية: النساء ، الانتشار ، التعليم ، الإجتماعية.. 